\title{
Some agricultural characteristics of soils in eastern-northeastern slopes of a volcanic cone: Şebinkarahisar Dikmen Hill (Giresun, Turkey) example
}

\author{
Hafize NALBANT¹, Bahadır ATMACA²
}

${ }^{1}$ Independent Researcher also Soil Specialist at TANAP Trans Anatolian Natural Gas Pipeline Project/Punj Lloyd-Limak-Kalyon Join Venture (LOT 4)

${ }^{2}$ Giresun University, Şebinkarahisar School of Applied Sciences, Department of Food Technology, Şebinkarahisar, GíRESUN

Alınış tarihi: 21 Kasım 2017, Kabul tarihi: 10 Nisan 2018

Sorumlu yazar: Bahadır ATMACA, e-posta:bahadiratmaca23@gmail.com

\begin{abstract}
This study was conducted with the aim to determine some agricultural characteristics of volcanic soils located on the slopes of a volcanic area and to give a preliminary idea for studies to be done. For this purpose, some agricultural characteristics of volcanic soils located on the eastern-northeastern slopes of Dikmen Hill, a volcanic cone, were determined. According to the analysis results of the 24 samples taken as surface soil $(0-30 \mathrm{~cm})$, the vast majority of the specimens were in the clay texture class. Available water values ranged from $1.11 \%$ to $41.45 \%$. The great majority of soils classified as entirely non-saline had neutral and slightly alkaline soil reactions. The amount of lime ranged from $0.55 \%$ to $46.02 \%$, while the content of organic matter ranged from $0.70 \%$ to $3.97 \%$. There were no potassium, calcium and magnesium deficiencies in the soil where deficiencies were found in terms of total nitrogen and phosphorus. Iron content is high in almost all soils where there was no deficiency in terms of copper. Zinc, manganese and boron deficiencies were identified. The findings suggest that proper fertilization programs should be prepared according to the macro and micro nutrient requirements before engaging in agriculture in the study area soils.
\end{abstract}

Key words: Volcanic soils, volcanic cone, agricultural characteristics, soil fertility
Volkanik bir koninin doğu-kuzeydoğu yamaçlarında yer alan toprakların bazı tarımsal özellikleri: Şebinkarahisar Dikmen Tepesi (Giresun, Türkiye) örneği

Öz

$\mathrm{Bu}$ çalışma, volkanik bir koninin yamaçlarında yer alan volkanik toprakların bazı tarımsal özelliklerini belirlemek ve yapılacak çalışmalar için bir ön fikir vermek amacıyla yapılmıștır. Bu amaçla, volkanik bir koni olan Dikmen Tepesi'nin doğu-kuzeydoğu yamaçlarında yer alan volkanik toprakların bazı tarımsal özellikleri belirlenmiştir. Yüzey toprağı (0$30 \mathrm{~cm}$ ) olarak alınan 24 adet örneğin analiz sonuçlarına göre; örneklerin çok büyük çoğunluğu kil tekstür sınıfındadır. Faydalı su değerleri \% 1.11 ile \% 41.45 arasında değişmektedir. Tamamı tuzsuz olarak sınıflandırılan toprakların büyük çoğunluğu nötr ve hafif alkali toprak reaksiyonlarına sahiptir. Kireç miktarları \% $0.55 \quad$ - $\% 46.02$ arasında değişirken, organik madde içerikleri de \% 0.70 ile \% 3.97 arasında değişmektedir. Toplam azot ve fosfor bakımından eksiklikler tespit edilen topraklarda, potasyum, kalsiyum ve magnezyum eksikliği bulunmamaktadır. Bakır açısından eksiklik bulunmayan toprakların tamamına yakınının demir içerikleri de yüksektir. Çinko, mangan ve bor bakımından eksiklikler tespit edilmiștir. Araștırma alanı topraklarında tarım yapılmadan önce makro ve mikro besin elemetlerine göre uygun gübreleme programı hazırlanmalıdır.

Anahtar kelimeler: Volkanik topraklar, volkanik koni, tarımsal özellikler, toprak verimliliği 


\section{Introduction}

The soil on which we live and which has an important place in the economy of every country covers the earth crust as a thin layer and emerges with the weathering of the rocks forming the earth crust and the organic materials, forms stall and nutritional source for vegetation (Cangir and Boyraz, 2006). The occurrence and evolution of the geographical formations seen on the surface of the lithosphere is a result of complex and at the same time variable factors and processes. One of the internal factors that have a profound effect on the formation of the earth surface is the volcanism (Erinç, 2012). A volcano consists of four sections as follows: a quarry, a chimney, a crater and a volcano cone. The material erupting out of the crater and piling around the mouth of the volcano forming a number of hills is called volcano cone. Lava flows downslope following the gradient of the slope. Those who are less fluid will cool off near the crater and help the volcano cone to grow. Cones piled up by volcanoes on the earth surface are continually eroded by the influence of external factors (Çakıroğlu and Korkut, 1950). Volcanic cones are the most common volcanic structures in the world (Kervyn et al., 2012).

Volcanic soils, among the most fertile lands in the world, cover $1 \%$ (over 124 million hectares) of the world's land surface and support $10 \%$ of the world's population, including some of the most populated areas in the world (Neall, 2009). The main reason for the close relationship between volcano and man is economical. The areas covered by volcano ash and the lands formed by the separation of the lavas are very convenient for agriculture and at the same time, it is also easy to process these lands (Çakıroğlu and Korkut, 1950).

Elevation, aspect and slope which are topographical factors, affect pedogenesis. For example, as a consequence of the gradient, the soil thickness is low on the slopes and greater on the plains. In the same way, on convex slopes, the soil is thicker than on concave slopes (Erinç, 2012). As the altitude increases, the decrease of the temperature, the increase of the rainfall, the distribution of the vegetation cover, along with the weathering events and the soil formation accordingly are directly affected. Soils formed along slopping surfaces are continually weathered. Thus, the effect of the parent material is seen on the soil. The direction any slope faces influences the intake of solar energy, the settlement of the vegetation cover its distribution and the weathering of the parent material (Atalay, 2014).

While the young eruptions have started partially in Oligocene in Turkey (Özcan, 2011), approximately $10.6 \%$ of the surface area of which is covered with volcanic rocks, the maximum intensity is reached in Miocene and Pliocene and continued strongly through Pleistocene (Erinç, 2012). Gürgen (1997) stated that young volcanic relief in Turkey occurs mostly related to young tectonic events in Tertiary and Quaternary. The Şebinkarahisar region is located in the south zone of the eastern section of the pontides tectonic unit (Ketin, 1966; Keskin, 2006). Cretaceous and Eocene volcano-sedimentary terrains, Miocene aged shallow marine sediments and Quaternary aged volcanic elements cutting across these, create the main geological elements of Şebinkarahisar region (Yürüdür, 1998).

Fine examples of young volcanic rocks and shapes formed by these are seen in the southern part of the Eastern Black Sea Region between Şebinkarahisar and Alucra. The field near the North Anatolian Fault zone includes various volcanic shapes formed by lavas upwelling to the surface after the young fractures efficient in this active tectonic belt. Volcanic cones all located on volcanic covers are also of these shapes. These cones, while being in the process of fragmentation today, still attract attention with their uniform shapes. The dominant rock types in volcanism are basalts. When examining the volcanic forms in the region, the occurrence of hills, such as volcano cone, roof along with broad shapes, such as mesa plateaus, the result showed that the lavas reaching the surface with volcanic activity were not only alkaline lavas. There were also medium or acidic lava flows at certain points or lava flows at different temperatures (Gürgen, 1997).

Neall (2009) argued that many of volcanic soils have excellent physical properties for a wide range of uses, they suffer from high phosphate uptake as chemically and can limit $\mathrm{K}$ and some micronutrients. The soils of volcanic cone areas in Auckland are generally rich in nutrients and comprise high levels of $\mathrm{P}$ when compared to the most natural soils in New Zealand. Also, unlike Maungawhau and Maungarei cones, comprising especially high organic matter and soil nitrogen, the Maungakiekie cone has the highest $\mathrm{P}$ levels. While the soils in the plane and slightly gradient areas contain higher $\mathrm{C}, \mathrm{N}$ and $\mathrm{P}$ than the gradient areas, the slopes in the north have a higher 
P content than the slopes in the south (Burns et al., 2013). Şenol et al. (2014) investigated the elemental losses (i.e., $\mathrm{Ca}, \mathrm{Mg}, \mathrm{K}, \mathrm{Na}, \mathrm{Si}, \mathrm{Al}$ and $\mathrm{Fe}$ ) of soils in Isparta Çünür Hill containing geologically volcanic sand, limestone and andesite/trachyandesite and weathering products. According to mass transport function values and mass losses/gains, losses and gains in the profiles on the southern slope were determined to exceed those in the northern slope profiles; so the aspect together with the position of the profile on the gradient terrain was important in these processes. Georgoulias and Moustakas (2010) took samples from seven different places on different parent materials and different ages, in the volcanic materials in Milos Island (Greece). Sand was identified between 19\%-92\%, silt between 3.5-50\% and clay between $5-46 \%$. The organic matter content was found to be low. The soil $\mathrm{pH}$ was reported to range from 5.6 to 8.0 and $\mathrm{CaCO}_{3}$ equivalents were detected to range from $1.4 \%$ to $24.6 \%$ in two of the profiles (Profile 2 and Profile 7). Drawing on eight soil profiles formed on volcanic parent material, research conducted by Uzun (2013) revealed that the sand and coarse silt fraction was over $30 \%$ in all of the soil, the bulk density was over $0.90 \mathrm{~g} \mathrm{~cm}^{-3}$ in all the profiles and the phosphorus fixation was detected to be generally low. Dingil et al. (2012) carried out research on soils formed from volcanic ashes in Turkey, and the findings indicated a total of more than $30 \%$ of sand and coarse silt fractions of a significant part of the soil and a bulk density of between $0.96-1.60 \mathrm{~g} \mathrm{~cm}^{-3}$, and $\mathrm{pH}$ values of 5.79 and 7.46 , respectively. Texture classes were reported as sandy loam (SL), sandy clay loam (SCL) and loam (L), while lime amounts were between $2.1 \%$ and $2.8 \%$, and organic matter values were between $0.7 \%$ and 5.9\%. Özdemir et al. (2008) took soil samples from areas of three different land uses as pasture, clover, and corn-wheat crop rotation together with the parent materials andesite, alluvial, gypsum and basalt in Erzurum. They reported that the soils were generally of loam texture, low and moderate level of organic matter and lime content, soils without alkalinity problem and that the distribution of the elements $\mathrm{Mn}, \mathrm{Fe}, \mathrm{Cu}$ and $\mathrm{Zn}$ was significantly affected by the type of the parent material and the use of land. They also found that the total micro element contents and distribution of fractions are generally higher in soils composed of andesite parent material than in the others. Yilmaz (1995) stated that cereal production, vineyards and orchards agriculture and animal husbandry were carried out in Şebinkarahisar.

One of the most prominent volcano cones reflected in the topography of Shebinkarahisar region is the Dikmen Hill $(1778 \mathrm{~m})$ located southwest of Şebinkarahisar (Gürgen, 1997; Yılmaz, 2006). This study aims to determine and evaluate some agricultural characteristics of volcanic soils on the eastern-northeastern slopes of Dikmen Hill, a volcanic cone and to give a preliminary idea for future research.

\section{Materials and Methods}

\section{Information on the research area}

Dikmen Hill with $1778 \mathrm{~m}$ altitude is located in Şebinkarahisar district of Giresun province east of Blacksea Region in Turkey. The location map of the study area was adapted and prepared from the maps of Saygilı (2015) and Anonymous (2016) (Figure 1). Keskin (2006) stated that, Miocene or younger basaltic volcanic rocks, that surfaced in the research area covering Şebinkarahisar district center and its immediate surroundings, for the first time, were named "Dikmen Volcanites" as a whole by Yllmaz et al. (1985). The unit is generally a dark gray, blackish color and the lava flow structures were dikes cutting across Miocene and older rocks in some places, and that porphyritic texture was prominent in both basaltic lavas and basalt dikes. Keskin (2006) also reported that this unit was located on the Şebinkarahisar Formation just western of Şebinkarahisar and that Dikmen Hill was a volcanic cone-shaped, probably one of the exits of young basalts. Yllmaz et al. (1985) highlighted that the thickness of this unit did not exceed $250 \mathrm{~m}$ and may be Miocene or of younger age. Looking at the geoscience map viewer and drawing editor provided by the Anonymous (2015), the study area covering the Dikmen Hill, and the sampling points were identified as Pliocene aged andesite for geological formation, and as Neogene Volcanites for magmatic rocks (Akbaş et al., 2015). Yılmaz (2006) discussed that Dikmen Hill is generally composed of basalt and andesites.

According to (Anonymous, 2017a) the climate data averages for the many years between 1964 and 2016 taken from Giresun Meteorology Station Directorate, the annual average temperature is $9.26^{\circ} \mathrm{C}$, with an average humidity of $60.6 \%$ in Şebinkarahisar. As a result of the observation of 49 years, the annual total precipitation amount is $517.2 \mathrm{~mm}$. 
The soil sampling was made in an area of about 1.12 $\mathrm{km}^{2}$ and according to the topographical features of research area. The soil samples used in the present study were taken from $0-30 \mathrm{~cm}$ depth as surface soil from 24 different locations on the easternnortheastern slopes of Dikmen Hill. The coordinates of the soil sampling sites and their elevations from the sea level were established with a 1-3 m sensitive GPS device (Magellan eXplorist 610) and are given in Table 1. The sampling locations were shown on the map using the VantagePoint program and the DigitalGlobe satellite image, the preview of which is provided in the said program (Figure 2). The slope and aspect maps of the study area (see Figure 3 and Figure 4) were prepared with ArcGIS Online, a cloudbased mapping platform (Anonymous 2017b).

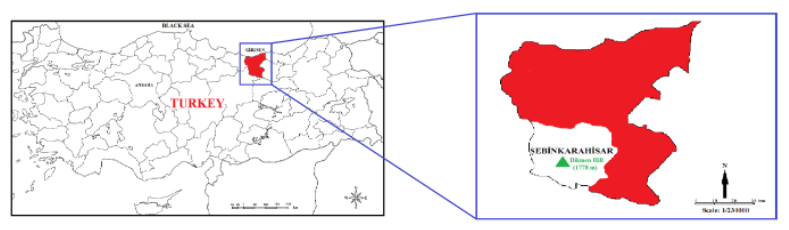

Figure 1. A location map of the study area.

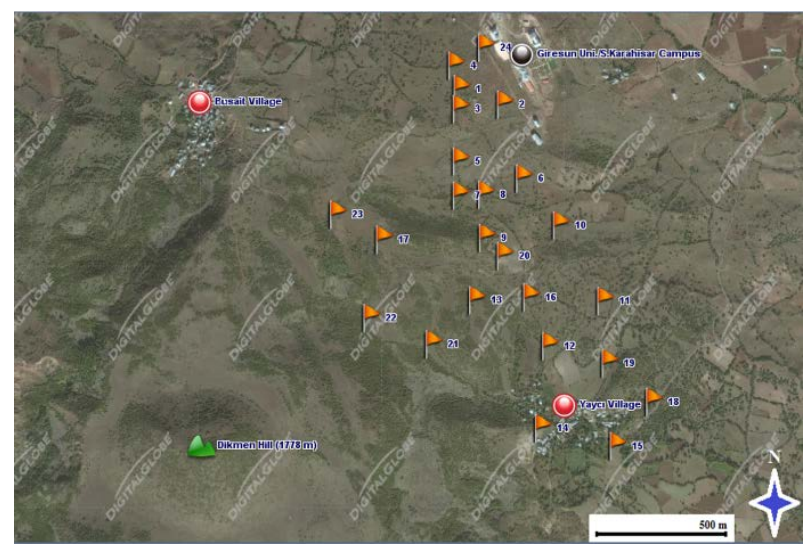

Figure 2. 1/9800 scale DigitalGlobe image showing immediate surroundings of Dikmen Hill and soil sampling points.

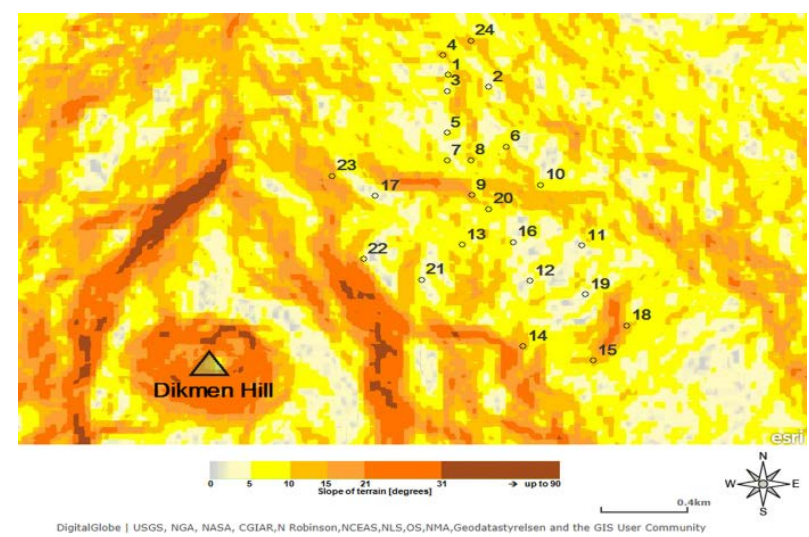

Figure 3. Slope index map of study area and soil sampling points.

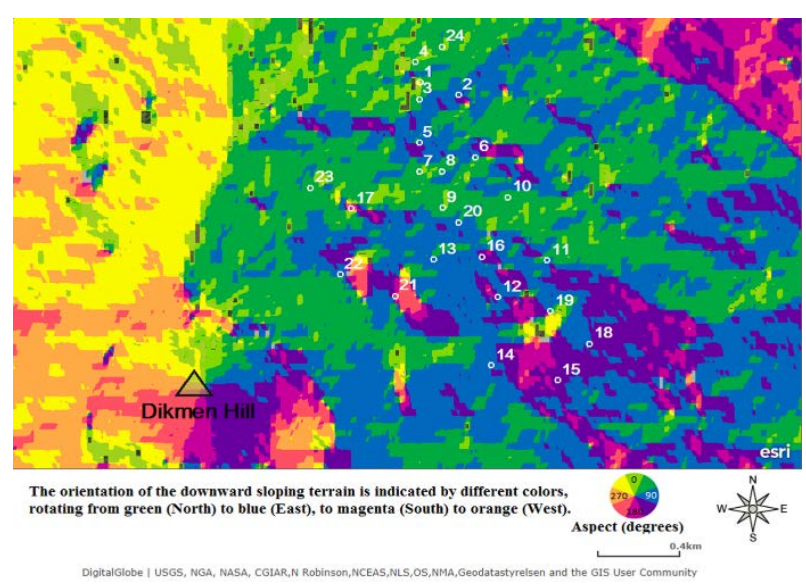

Figure 4. Aspect map of study area and soil sampling points.

Table 1. Coordinates and elevations from the sea level of soil sampling sites

\begin{tabular}{|c|c|c|c|}
\hline \multirow{2}{*}{ Sample No. } & \multicolumn{2}{|c|}{ Coordinates* } & \multirow{2}{*}{$\begin{array}{l}\begin{array}{c}\text { Elevations from } \\
\text { the sea level }(\mathrm{m})\end{array} \\
1456\end{array}$} \\
\hline & $40^{\circ} 16^{\prime} 52^{\prime \prime} \mathrm{N}$ & $38^{\circ} 23^{\prime} 13^{\prime \prime E}$ & \\
\hline 2 & $40^{\circ} 16^{\prime} 50^{\prime \prime} \mathrm{N}$ & $38^{\circ} 23^{\prime} 20^{\prime \prime} \mathrm{E}$ & 1447 \\
\hline 3 & $40^{\circ} 16^{\prime} 50^{\prime \prime} \mathrm{N}$ & $38^{\circ} 23^{\prime} 13^{\prime \prime E}$ & 1470 \\
\hline 4 & $40^{\circ} 16^{\prime} 55^{\prime \prime} \mathrm{N}$ & $38^{\circ} 23^{\prime} 12^{\prime \prime E}$ & 1448 \\
\hline 5 & $40^{\circ} 16^{\prime} 43^{\prime \prime} \mathrm{N}$ & $38^{\circ} 23^{\prime} 13^{\prime \prime E}$ & 1476 \\
\hline 6 & $40^{\circ} 16^{\prime} 41^{\prime \prime} \mathrm{N}$ & $38^{\circ} 23^{\prime} 23^{\prime \prime E}$ & 1448 \\
\hline 7 & $40^{\circ} 16^{\prime} 39^{\prime \prime} \mathrm{N}$ & $38^{\circ} 23^{\prime} 13^{\prime \prime E}$ & 1475 \\
\hline 8 & $40^{\circ} 16^{\prime} 39^{\prime \prime} \mathrm{N}$ & $38^{\circ} 23^{\prime} 17^{\prime \prime E}$ & 1468 \\
\hline 9 & $40^{\circ} 16^{\prime} 33^{\prime \prime} \mathrm{N}$ & $38^{\circ} 23^{\prime} 17^{\prime \prime E}$ & 1486 \\
\hline 10 & $40^{\circ} 16^{\prime} 35^{\prime \prime} \mathrm{N}$ & $38^{\circ} 23^{\prime} 29^{\prime \prime E}$ & 1441 \\
\hline 11 & $40^{\circ} 16^{\prime} 26^{\prime \prime} \mathrm{N}$ & $38^{\circ} 23^{\prime} 36^{\prime \prime E}$ & 1450 \\
\hline 12 & $40^{\circ} 16^{\prime} 20^{\prime \prime} \mathrm{N}$ & $38^{\circ} 23^{\prime} 27^{\prime \prime E}$ & 1460 \\
\hline 13 & $40^{\circ} 16^{\prime} 26^{\prime \prime} \mathrm{N}$ & $38^{\circ} 23^{\prime} 15^{\prime \prime E}$ & 1501 \\
\hline 14 & $40^{\circ} 16^{\prime} 10^{\prime \prime} \mathrm{N}$ & $38^{\circ} 23^{\prime} 26^{\prime \prime} \mathrm{E}$ & 1460 \\
\hline 15 & $40^{\circ} 16^{\prime} 07^{\prime \prime} \mathrm{N}$ & $38^{\circ} 23^{\prime} 38^{\prime \prime} \mathrm{E}$ & 1421 \\
\hline 16 & $40^{\circ} 16^{\prime} 26^{\prime \prime} \mathrm{N}$ & $38^{\circ} 23^{\prime} 24^{\prime \prime} \mathrm{E}$ & 1471 \\
\hline 17 & $40^{\circ} 16^{\prime} 33^{\prime \prime} \mathrm{N}$ & $38^{\circ} 23^{\prime} 00^{\prime \prime E}$ & 1526 \\
\hline 18 & $40^{\circ} 16^{\prime} 13^{\prime \prime} \mathrm{N}$ & $38^{\circ} 23^{\prime} 44^{\prime \prime E}$ & 1421 \\
\hline 19 & $40^{\circ} 16^{\prime} 18^{\prime \prime} \mathrm{N}$ & $38^{\circ} 23^{\prime} 37^{\prime \prime E}$ & 1447 \\
\hline 20 & $40^{\circ} 16^{\prime} 31^{\prime \prime} \mathrm{N}$ & $38^{\circ} 23^{\prime} 20^{\prime \prime} \mathrm{E}$ & 1490 \\
\hline 21 & $40^{\circ} 16^{\prime} 20^{\prime \prime} \mathrm{N}$ & $38^{\circ} 23^{\prime} 08^{\prime \prime E}$ & 1506 \\
\hline 22 & $40^{\circ} 16^{\prime} 23^{\prime \prime} \mathrm{N}$ & $38^{\circ} 22^{\prime} 58^{\prime \prime} \mathrm{E}$ & 1532 \\
\hline 23 & $40^{\circ} 16^{\prime} 36^{\prime \prime} \mathrm{N}$ & $38^{\circ} 22^{\prime} 52^{\prime \prime E}$ & 1539 \\
\hline 24 & $40^{\circ} 16^{\prime} 58^{\prime \prime} \mathrm{N}$ & $38^{\circ} 23^{\prime} 17^{\prime \prime E}$ & 1436 \\
\hline
\end{tabular}

*N: North, E: East

\section{Methods and evaluation criteria of soil analysis}

Spoiled soil samples taken from the study area were prepared for analyses by sieving using sieves appropriate according to the analyses. Particle size distribution (texture) was determined by the hydrometer method (Bouyoucos, 1951). While the textures of soil samples $(9,10,11,14,20$ and 23) containing very high lime were determined, lime was removed according to Baver (1956). Texture triangles were used in the naming of texture classes (Anonymous, 1993). Lime was determined by the volumetric calcimeter method; total nitrogen content (\%) was determined by Kjeldahl method (Sağlam, 
2008). $\mathrm{pH}$ was measured using a $\mathrm{pH}$ meter in $1: 2.5$ water; salt (\%) was calculated using the value given by conductivity meter depending on the electrical conductivity in 1:2.5 water and organic matter content (\%) was determined via Modified WalkleyBlack Method (Kacar, 1995). Interpretation of soil reaction and salt values were made according to Richards (1954). Lime and organic matter contents were interpreted according Anonymous (1988). Bulk density was estimated (see Black, 1965). Particle density was achieved using degraded soil samples with the pycnometer method (Black, 1965). Total porosity was found using Cangir's method (1991). The amount of boron in the hot water extract of the soil was directly read in ICP-OES (Wolf, 1971). Boron values were interpreted based on Bray's (1948) study. Field capacity and wilting point percent were determined according to Veihmeyer and Hendrickson (1949). Available water percent was calculated by subtracting from the field capacity value to wilting point value (Sağlam et al., 1993a). Phosphorus was determined in the ICP-OES by the Olsen method (Anonymous, 1990) and converted to $\mathrm{kg} \mathrm{da} \mathrm{da}^{-1}$ according to Sağlam (2008). Potassium (Anonymous, 1990), calcium and magnesium (ppm); was determined in ICP after extraction with ammonium acetate (Kacar, 1995). Potassium was converted to $\mathrm{kg} \mathrm{da}^{-1}$ according to Sağlam (2008). Total nitrogen content values were interpreted according to Anonymous (1990). Phosphorous and potassium interpretations were made according to Anonymous (1988) and calcium and magnesium interpretations were made according to Alpaslan et al. (2005). The exchangeable sodium was determined by atomic absorption spectrophotometer in the extraction by $1 \mathrm{~N}$ ammonium acetate extraction and iron, copper, zinc, and manganese were determined in ppm by using the ICP after extraction by DTPA (Kacar, 1995). Iron was interpreted according to Lindsay and Norvell (1969); copper, according to Follett (1969); zinc and manganese based on Anonymous (1990).

\section{Results and Discussion}

Some physical analysis results of 24 surface soil (0$30 \mathrm{~cm}$ ) samples used in the study are presented in Table 2 . The total porosity values of the survey soil were between $40.87 \%$ (sample no. 24) and $57.66 \%$ (sample no. 22). The field capacity values of soil samples varied between $30.62 \%$ and $90.02 \%$; and the wilting point values between $16.25 \%$ and
$82.32 \%$. According to the field capacity and wilting point values, the highest values were determined in sample no. 1 and the lowest values were determined in sample no. 23. Concerning available water values, the lowest value belonged to sample no. 2 with $1.11 \%$; the highest value belonged to sample no. 3 with $41.45 \%$. The particle density values of the soil samples were $2.14-2.75 \mathrm{~g} \mathrm{~cm}^{-3}$. Sample no. $15 \mathrm{had}$ the lowest particle density and the sample no. 23 has the highest particle density values. According to the bulk density values of $1.13-1.37 \mathrm{~g} \mathrm{~cm}^{-3}$, the sample no. 5 had the lowest and the sample no. 1 has the highest bulk density.

Texture values and texture classes and some chemical properties of surface soil samples in the study area are given in Table 3. According to this, the highest sand content of the soil samples was $52.57 \%$ with sample no. 23 and $11.90 \%$ the lowest sand content with sample no. 4. Examined the silt content, values between $16.70 \%$ (sample no. 23) - 39.32\% (sample no. 22) were determined. The clay contents of soil samples were determined to be the highest (64.30\%) in sample no. 4 and lowest $(30.73 \%)$ in sample no. 23. The soil $\mathrm{pH}$ values ranged from 6.42 to 7.85. The organic matter content, the amount of lime and salt values of the soil varied between 0.70 $3.97 \%, 0.55-46.02 \%, 0.00-0.04 \%$, respectively.

Minimum, maximum and average values of some physical and chemical analysis results of soil samples used in the study are presented in Table 4.

Some macro element contents of surface soil samples used in the research are given in Table 5. The total nitrogen values of the soil varied 0.02 $0.20 \%$. Phosphorus $\left(\mathrm{P}_{2} \mathrm{O}_{5}\right)$ levels of which ranged $1.89 \mathrm{~kg} \mathrm{da}^{-1}-16.42 \mathrm{~kg} \mathrm{da}^{-1}$, also potassium $\left(\mathrm{K}_{2} \mathrm{O}\right)$ levels ranging from $44.50 \mathrm{~kg} \mathrm{da}^{-1}$ to $383.00 \mathrm{~kg} \mathrm{da}^{-1}$. The calcium values of soil samples ranged 2541.03$11382.45 \mathrm{ppm}$, and the magnesium values ranged 134.05-1410.42 ppm. The sodium contents of soils ranged 7.21-90.07 ppm. Some micro element contents of the research soils are presented in Table 6. Iron contents varied $3.58 \mathrm{ppm}$ - $58.78 \mathrm{ppm}$; copper quantities range from $0.60 \mathrm{ppm}$ to $3.77 \mathrm{ppm}$. When zinc content is examined, values ranging from $0.07 \mathrm{ppm}$ to $0.89 \mathrm{ppm}$ were seen. The manganese contents were also between $1.94 \mathrm{ppm}$ and 80.69 $\mathrm{ppm}$. The boron contents of the samples ranged 0.12 ppm - 1.45 ppm. 
Table 2. Some physical analysis results of the soils

\begin{tabular}{|c|c|c|c|c|c|c|}
\hline $\begin{array}{l}\text { Samples and Depth } \\
\text { (cm) }\end{array}$ & $\begin{array}{l}\mathrm{FC}^{* *} \\
(\%)\end{array}$ & $\begin{array}{l}\text { WP** } \\
(\%)\end{array}$ & $\begin{array}{c}\mathrm{AW}^{* *} \\
(\%)\end{array}$ & $\begin{array}{l}\mathrm{PD}^{* *} \\
\left(\mathrm{~g} \mathrm{~cm}^{-3}\right)\end{array}$ & $\begin{array}{l}\mathrm{BD}^{* *} \\
\left(\mathrm{~g} \mathrm{~cm}^{-3}\right)\end{array}$ & $\begin{array}{c}\text { Total } \\
\mathrm{P}^{* *} \\
(\%)\end{array}$ \\
\hline $1(0-30)$ & 90.02 & 82.32 & 7.70 & 2.60 & 1.37 & 47.31 \\
\hline $2(0-30)$ & 41.00 & 39.89 & 1.11 & 2.40 & 1.35 & 43.75 \\
\hline $3(0-30)$ & 75.31 & 33.86 & 41.45 & 2.35 & 1.34 & 42.98 \\
\hline $4(0-30)$ & 52.17 & 38.24 & 13.93 & 2.65 & 1.29 & 51.32 \\
\hline $5(0-30)$ & 46.12 & 37.57 & 8.55 & 2.55 & 1.13 & 55.69 \\
\hline $6(0-30)$ & 66.99 & 41.78 & 25.21 & 2.24 & 1.20 & 46.43 \\
\hline $7(0-30)$ & 38.73 & 35.28 & 3.45 & 2.49 & 1.35 & 45.78 \\
\hline $8(0-30)$ & 35.94 & 34.46 & 1.48 & 2.64 & 1.19 & 54.92 \\
\hline $9(0-30)$ & 56.28 & 21.08 & 35.20 & 2.61 & 1.14 & 56.32 \\
\hline $10(0-30)$ & 51.56 & 31.63 & 19.93 & 2.61 & 1.14 & 56.32 \\
\hline $11(0-30)$ & 51.15 & 28.45 & 22.70 & 2.50 & 1.25 & 50.00 \\
\hline $12(0-30)$ & 58.68 & 27.37 & 31.31 & 2.35 & 1.24 & 47.23 \\
\hline $13(0-30)$ & 46.12 & 29.80 & 16.32 & 2.66 & 1.31 & 50.75 \\
\hline $14(0-30)$ & 36.86 & 27.32 & 9.54 & 2.50 & 1.23 & 50.80 \\
\hline $15(0-30)$ & 55.68 & 28.99 & 26.69 & 2.14 & 1.14 & 46.73 \\
\hline $16(0-30)$ & 53.82 & 28.13 & 25.69 & 2.76 & 1.17 & 57.61 \\
\hline $17(0-30)$ & 50.32 & 31.01 & 19.31 & 2.58 & 1.26 & 51.16 \\
\hline $18(0-30)$ & 41.92 & 21.67 & 20.25 & 2.52 & 1.26 & 50.00 \\
\hline $19(0-30)$ & 43.94 & 21.31 & 22.63 & 2.61 & 1.14 & 56.32 \\
\hline $20(0-30)$ & 36.93 & 17.94 & 18.99 & 2.49 & 1.16 & 53.41 \\
\hline $21(0-30)$ & 37.51 & 19.69 & 17.82 & 2.72 & 1.21 & 55.51 \\
\hline $22(0-30)$ & 37.22 & 16.74 & 20.48 & 2.74 & 1.16 & 57.66 \\
\hline $23(0-30)$ & 30.62 & 16.25 & 14.37 & 2.75 & 1.24 & 54.91 \\
\hline $24(0-30)$ & 53.83 & 26.53 & 27.30 & 2.30 & 1.36 & 40.87 \\
\hline
\end{tabular}

** FC: Field Capacity, WP: Wilting Point, AW: Available Water (FC-WP), PD: Particle Density,

BD: Bulk Density, P: Porosity

Table 3. Texture information and some chemical properties of the soils

\begin{tabular}{|c|c|c|c|c|c|c|c|c|}
\hline $\begin{array}{l}\text { Samples } \\
\text { and Depth } \\
(\mathrm{cm})\end{array}$ & $\begin{array}{l}\text { Sand } \\
(\%)\end{array}$ & $\begin{array}{l}\text { Silt } \\
(\%)\end{array}$ & $\begin{array}{l}\text { Clay } \\
(\%)\end{array}$ & $\begin{array}{l}\text { Texture } \\
\text { Class*** }\end{array}$ & $\begin{array}{c}\mathrm{pH} \\
(1: 2.5)\end{array}$ & $\begin{array}{l}\text { Salt } \\
(\%)\end{array}$ & $\begin{array}{c}\mathrm{CaCO}_{3} \\
(\%)\end{array}$ & $\begin{array}{c}\mathrm{OM}^{* * *} \\
(\%)\end{array}$ \\
\hline $1(0-30)$ & 18.07 & 28.24 & 53.69 & $\mathrm{C}$ & 6.86 & 0.04 & 0.83 & 1.50 \\
\hline $2(0-30)$ & 26.60 & 21.14 & 52.26 & $\mathrm{C}$ & 6.62 & 0.01 & 0.74 & 0.70 \\
\hline $3(0-30)$ & 21.46 & 21.39 & 57.15 & $\mathrm{C}$ & 6.42 & 0.01 & 0.64 & 2.57 \\
\hline $4(0-30)$ & 11.90 & 23.80 & 64.30 & $\mathrm{C}$ & 6.79 & 0.01 & 1.01 & 1.59 \\
\hline $5(0-30)$ & 22.23 & 21.77 & 56.00 & $\mathrm{C}$ & 7.59 & 0.01 & 1.56 & 0.85 \\
\hline $6(0-30)$ & 26.47 & 23.99 & 49.54 & $\mathrm{C}$ & 7.36 & 0.02 & 1.84 & 2.78 \\
\hline $7(0-30)$ & 21.29 & 23.58 & 55.13 & $\mathrm{C}$ & 7.21 & 0.01 & 1.29 & 2.76 \\
\hline $8(0-30)$ & 23.21 & 21.50 & 55.29 & $\mathrm{C}$ & 7.67 & 0.01 & 7.09 & 2.38 \\
\hline $9(0-30)$ & 26.34 & 29.70 & 43.96 & $\mathrm{C}$ & 7.80 & 0.01 & 31.48 & 1.17 \\
\hline $10(0-30)$ & 29.81 & 19.31 & 50.88 & $\mathrm{C}$ & 7.75 & 0.01 & 28.26 & 3.03 \\
\hline $11(0-30)$ & 15.29 & 25.59 & 59.12 & $\mathrm{C}$ & 7.84 & 0.01 & 29.92 & 1.96 \\
\hline $12(0-30)$ & 24.46 & 31.72 & 43.82 & $\mathrm{C}$ & 7.48 & 0.01 & 0.64 & 2.86 \\
\hline $13(0-30)$ & 19.17 & 21.43 & 59.40 & $\mathrm{C}$ & 6.88 & 0.01 & 0.92 & 2.23 \\
\hline $14(0-30)$ & 14.20 & 35.82 & 49.98 & $\mathrm{C}$ & 7.56 & 0.01 & 29.46 & 3.97 \\
\hline $15(0-30)$ & 23.62 & 23.52 & 52.86 & $\mathrm{C}$ & 7.74 & 0.02 & 10.13 & 3.46 \\
\hline $16(0-30)$ & 20.91 & 28.00 & 51.09 & $\mathrm{C}$ & 7.70 & 0.01 & 6.35 & 3.18 \\
\hline $17(0-30)$ & 14.71 & 25.77 & 59.52 & $\mathrm{C}$ & 7.34 & 0.01 & 0.55 & 2.80 \\
\hline $18(0-30)$ & 21.34 & 33.36 & 45.30 & $\mathrm{C}$ & 6.71 & 0.00 & 0.74 & 2.80 \\
\hline $19(0-30)$ & 25.43 & 29.23 & 45.34 & $\mathrm{C}$ & 6.87 & 0.01 & 0.74 & 3.27 \\
\hline $20(0-30)$ & 16.76 & 33.53 & 49.71 & $\mathrm{C}$ & 7.85 & 0.01 & 46.02 & 1.62 \\
\hline $21(0-30)$ & 23.63 & 33.28 & 43.09 & $\mathrm{C}$ & 7.08 & 0.01 & 1.47 & 1.95 \\
\hline $22(0-30)$ & 21.95 & 39.32 & 38.73 & CL & 7.02 & 0.01 & 0.74 & 2.45 \\
\hline $23(0-30)$ & 52.57 & 16.70 & 30.73 & SCL & 7.72 & 0.01 & 44.37 & 2.24 \\
\hline $24(0-30)$ & 21.69 & 19.19 & 59.12 & $\mathrm{C}$ & 6.88 & 0.01 & 0.55 & 1.03 \\
\hline
\end{tabular}

*** C: Clay, CL: Clay loam, SCL: Sandy clay loam; OM: Organic matter 
Table 4. Minimum, maximum and average values of some physical and chemical analysis results of soil samples

\begin{tabular}{cccc}
\hline Soil Properties & Minimum & Maximum & Average \\
\hline FC (\%) & 30.62 & 90.02 & 49.53 \\
WP (\%) & 16.25 & 82.32 & 30.72 \\
AW (\%) & 1.11 & 41.45 & 18.81 \\
PD $\left(\mathrm{g} \mathrm{cm}^{-3}\right)$ & 2.14 & 2.75 & 2.53 \\
BD $\left(\mathrm{g} \mathrm{cm}^{-3}\right)$ & 1.13 & 1.37 & 1.23 \\
Total P (\%) & 40.87 & 57.66 & 50.99 \\
Sand (\%) & 11.90 & 52.57 & 22.63 \\
Silt (\%) & 16.70 & 39.32 & 26.29 \\
Clay(\%) & 30.73 & 64.30 & 51.08 \\
pH (1:2.5) & 6.42 & 7.85 & 7.28 \\
Salt (\%) & 0.00 & 0.04 & 0.01 \\
CaCO $(\%)$ & 0.55 & 46.02 & 10.31 \\
OM (\%) & 0.70 & 3.97 & 2.30 \\
\hline
\end{tabular}

When all of the research soils were evaluated in terms of slope: It has been determined that sample points no. 4, 6, 9, 14, 15, 18, 22, 23 and 24 had higher gradients and the sample points no. 2, 3, 5, 11, 12, $16,17,19$ and 21 had lower gradients. The available soil water values of samples at areas with high gradients were 9.54-35.20\%; the organic matter values $1.03-3.97 \%$; the total nitrogen values 0.05 $0.15 \%$; the phosphorus contents $1.93 \mathrm{~kg} \mathrm{da}^{-1}$ and $16.42 \mathrm{~kg} \mathrm{da}^{-1}$; the zinc contents $0.07-0.89 \mathrm{ppm}$; the manganese values ranged from $2.55 \mathrm{ppm}$ to 80.69 ppm and boron values ranged from 0.12-1.45 ppm. The available soil water values of samples at areas with low gradients were $1.11-41.45 \%$; the organic matter values $0.70-3.27 \%$; the total nitrogen values $0.02-0.20 \%$; the phosphorus contents $2.24 \mathrm{~kg} \mathrm{da}^{-1}$ and $13.57 \mathrm{~kg} \mathrm{da}^{-1}$; the zinc contents $0.13-0.55 \mathrm{ppm}$; the manganese values range from $8.01 \mathrm{ppm}$ to 79.71 ppm and boron values range from 0.16-0.92 ppm.

Table 5. Analysis results of some macro element contents of soil samples

\begin{tabular}{|c|c|c|c|c|c|c|}
\hline $\begin{array}{c}\text { Samples and } \\
\text { Depth } \\
\text { (cm) }\end{array}$ & $\begin{array}{c}\text { Total } \\
\mathrm{N} \\
(\%)\end{array}$ & $\begin{array}{c}\mathrm{P} \\
\left(\mathrm{P}_{2} \mathrm{O}_{5}\right) \\
\left(\mathrm{kg} \mathrm{da}^{-1}\right)\end{array}$ & $\begin{array}{c}\mathrm{K} \\
\left(\mathrm{K}_{2} \mathrm{O}\right) \\
\left(\mathrm{kg} \mathrm{da}^{-1}\right)\end{array}$ & $\begin{array}{c}\mathrm{Ca} \\
(\mathrm{ppm})\end{array}$ & $\begin{array}{c}\mathrm{Mg} \\
(\mathrm{ppm})\end{array}$ & $\begin{array}{c}\mathrm{Na} \\
(\mathrm{ppm})\end{array}$ \\
\hline $1(0-30)$ & 0.02 & 6.86 & 100.00 & 5574.28 & 1323.31 & 40.78 \\
\hline $2(0-30)$ & 0.09 & 7.82 & 100.00 & 5034.06 & 930.91 & 35.59 \\
\hline $3(0-30)$ & 0.10 & 6.46 & 75.15 & 5541.61 & 1221.81 & 62.14 \\
\hline $4(0-30)$ & 0.07 & 4.23 & 125.00 & 8360.23 & 1281.16 & 40.53 \\
\hline $5(0-30)$ & 0.02 & 3.01 & 129.00 & 11352.90 & 346.80 & 16.56 \\
\hline $6(0-30)$ & 0.15 & 3.70 & 134.50 & 9588.54 & 1156.35 & 81.94 \\
\hline $7(0-30)$ & 0.19 & 4.45 & 136.00 & 6407.86 & 1410.42 & 69.29 \\
\hline $8(0-30)$ & 0.09 & 3.97 & 163.00 & 11382.45 & 296.39 & 12.64 \\
\hline $9(0-30)$ & 0.06 & 1.93 & 48.50 & 10409.85 & 134.05 & 8.15 \\
\hline $10(0-30)$ & 0.14 & 2.87 & 116.00 & 10803.45 & 402.23 & 12.59 \\
\hline $11(0-30)$ & 0.09 & 2.24 & 122.30 & 10386.45 & 631.38 & 18.95 \\
\hline $12(0-30)$ & 0.20 & 4.64 & 88.80 & 6037.14 & 468.91 & 32.71 \\
\hline $13(0-30)$ & 0.04 & 3.37 & 78.90 & 5068.37 & 1136.21 & 42.54 \\
\hline $14(0-30)$ & 0.07 & 12.64 & 275.00 & 8587.96 & 298.26 & 11.72 \\
\hline $15(0-30)$ & 0.13 & 16.42 & 383.00 & 9170.51 & 367.05 & 15.38 \\
\hline $16(0-30)$ & 0.10 & 3.66 & 129.50 & 11292.90 & 202.58 & 14.54 \\
\hline $17(0-30)$ & 0.06 & 3.58 & 107.00 & 7950.72 & 816.52 & 18.50 \\
\hline $18(0-30)$ & 0.09 & 7.67 & 167.00 & 3460.28 & 479.91 & 17.44 \\
\hline $19(0-30)$ & 0.14 & 13.57 & 251.00 & 3642.91 & 408.62 & 13.18 \\
\hline $20(0-30)$ & 0.02 & 1.89 & 48.90 & 9236.49 & 210.69 & 7.21 \\
\hline $21(0-30)$ & 0.07 & 5.68 & 82.00 & 3310.00 & 628.42 & 30.53 \\
\hline $22(0-30)$ & 0.10 & 8.87 & 138.50 & 2541.03 & 437.71 & 14.94 \\
\hline $23(0-30)$ & 0.05 & 2.28 & 44.50 & 8303.23 & 172.82 & 7.85 \\
\hline $24(0-30)$ & 0.06 & 4.59 & 97.00 & 4436.91 & 1203.97 & 90.07 \\
\hline
\end{tabular}


Table 6. Analysis results of some micro element contents of soil samples

\begin{tabular}{|c|c|c|c|c|c|}
\hline $\begin{array}{l}\text { Samples and Depth } \\
(\mathrm{cm})\end{array}$ & $\begin{array}{c}\mathrm{Fe} \\
(\mathrm{ppm})\end{array}$ & $\begin{array}{c}\mathrm{Cu} \\
(\mathrm{ppm})\end{array}$ & $\begin{array}{c}\mathrm{Zn} \\
(\mathrm{ppm})\end{array}$ & $\begin{array}{c}\mathrm{Mn} \\
(\mathrm{ppm})\end{array}$ & $\begin{array}{c}\mathrm{B} \\
(\mathrm{ppm})\end{array}$ \\
\hline $1(0-30)$ & 36.62 & 2.46 & 0.85 & 53.42 & 0.35 \\
\hline $2(0-30)$ & 31.26 & 3.10 & 0.44 & 79.71 & 0.42 \\
\hline $3(0-30)$ & 49.50 & 2.18 & 0.35 & 37.28 & 0.16 \\
\hline $4(0-30)$ & 23.54 & 2.37 & 0.29 & 49.11 & 0.42 \\
\hline $5(0-30)$ & 8.89 & 2.07 & 0.21 & 8.01 & 0.62 \\
\hline $6(0-30)$ & 16.96 & 2.66 & 0.36 & 14.29 & 0.69 \\
\hline $7(0-30)$ & 33.79 & 3.69 & 0.34 & 20.01 & 0.44 \\
\hline $8(0-30)$ & 10.40 & 2.12 & 0.22 & 10.16 & 0.56 \\
\hline $9(0-30)$ & 4.47 & 0.97 & 0.21 & 2.55 & 0.26 \\
\hline $10(0-30)$ & 8.28 & 1.49 & 0.17 & 8.89 & 0.49 \\
\hline $11(0-30)$ & 7.33 & 1.64 & 0.13 & 11.72 & 0.45 \\
\hline $12(0-30)$ & 25.98 & 3.18 & 0.27 & 9.41 & 0.32 \\
\hline $13(0-30)$ & 24.86 & 1.78 & 0.21 & 30.59 & 0.14 \\
\hline $14(0-30)$ & 4.76 & 1.37 & 0.89 & 4.43 & 1.27 \\
\hline $15(0-30)$ & 5.63 & 2.63 & 0.82 & 7.58 & 1.45 \\
\hline $16(0-30)$ & 6.51 & 2.07 & 0.21 & 9.69 & 0.60 \\
\hline $17(0-30)$ & 14.71 & 1.88 & 0.27 & 20.36 & 0.42 \\
\hline $18(0-30)$ & 58.78 & 3.77 & 0.48 & 52.91 & 0.57 \\
\hline $19(0-30)$ & 38.14 & 2.83 & 0.55 & 58.55 & 0.92 \\
\hline $20(0-30)$ & 3.58 & 0.60 & 0.11 & 1.94 & 0.22 \\
\hline $21(0-30)$ & 34.33 & 2.36 & 0.22 & 25.80 & 0.27 \\
\hline $22(0-30)$ & 50.08 & 2.57 & 0.50 & 80.69 & 0.54 \\
\hline $23(0-30)$ & 6.07 & 0.78 & 0.07 & 4.57 & 0.27 \\
\hline $24(0-30)$ & 32.67 & 1.57 & 0.23 & 18.42 & 0.12 \\
\hline
\end{tabular}

Minimum, maximum and average values of some macro and micro element contents of soil samples used in the research are given in Table 7.

Table 7. Minimum, maximum and average values of some macro and micro element contents of soil samples

\begin{tabular}{cccc}
\hline Soil Properties & Minimum & Maximum & Average \\
\hline Total $\mathrm{N}(\%)$ & 0.02 & 0.20 & 0.09 \\
$\mathrm{P}\left(\mathrm{P}_{2} \mathrm{O}_{5}\right)\left(\mathrm{kg} \mathrm{da}^{-1}\right)$ & 1.89 & 16.42 & 5.68 \\
$\mathrm{~K}\left(\mathrm{~K}_{2} \mathrm{O}\right)\left(\mathrm{kg} \mathrm{da}^{-1}\right)$ & 44.50 & 383.00 & 130.86 \\
$\mathrm{Ca}(\mathrm{ppm})$ & 2541.03 & 11382.45 & 7411.67 \\
$\mathrm{Mg}(\mathrm{ppm})$ & 134.05 & 1410.42 & 665.27 \\
$\mathrm{Na}(\mathrm{ppm})$ & 7.21 & 90.07 & 29.82 \\
$\mathrm{Fe}(\mathrm{ppm})$ & 3.58 & 58.78 & 22.38 \\
$\mathrm{Cu}(\mathrm{ppm})$ & 0.60 & 3.77 & 2.17 \\
$\mathrm{Zn}(\mathrm{ppm})$ & 0.07 & 0.89 & 0.35 \\
$\mathrm{Mn}(\mathrm{ppm})$ & 1.94 & 80.69 & 25.84 \\
$\mathrm{~B}(\mathrm{ppm})$ & 0.12 & 1.45 & 0.50 \\
\hline
\end{tabular}

The high porosity of the clay soils results in the water holding capacity high. In sandy soils, amount of available water is low because the amount of water retained at field capacity and the wilting point is low. The same is the case for clay soils. The field capacity of clay soil is high, but as the wilting point is also high, the amount of water available is low (Karaçal, 2008). Texture classes of the Dikmen Hill study soils are as follows: All other soil samples used in the study are in clay (C) texture class, except for sample no. 22 in the clay loam (CL) texture class and sample no. 23 in the sandy clay loam (SCL) texture class. The total porosity values of all study soils were found to be over $40 \%$. The majority of the samples have a field capacity value of above $40 \%$, and wilting point values of 10 samples are more than $30 \%$. Six samples with field capacity and wilting point values close to each other have available water values below $10 \%$. FC and WP values of sample 1 are found to be very high. Compared with the other samples, it is seen that there are much lower results in the samples with higher clay, silt and organic matter amount. It is recommended that the clay minerals of the soils in the study area to be examined.

From an agricultural point of view, increasing bulk density usually inhibits plant root development (Sağlam et al., 1993a). Aydın and Kılıç (2010) stated that the bulk density is half of the average particle density of soil if half of the total volume consists of pore sand is between $1.30-1.35 \mathrm{~g} \mathrm{~cm}^{-3}$ values. This value can increase up to as much as $1.6 \mathrm{~g} \mathrm{~cm}^{-3}$ for sandy soils, whereas aggregated loam and clay soils can reach a value of $1.1 \mathrm{~g} \mathrm{~cm}^{-3}$. The particle density values of the soils in the study area are between 2.14-2.75 $\mathrm{g} \mathrm{cm}^{-3}$; bulk density values are 1.13-1.37 $\mathrm{g}$ $\mathrm{cm}^{-3}$.

Aeration, water retention, heating and colloidal properties of soil, chemical behaviors such as plant nutrient content are closely related to texture (Karaçal, 2008). The usefulness of the elements, which are absolutely necessary for the development of plants, is closely related to the $\mathrm{pH}$ of the growth 
environment or the activity of hydrogen ions (Kacar, 2009). $54.17 \%$ of the soil samples in the classification are neutral and $41.67 \%$ have slightly alkaline soil reactions. The soil reaction of sample no. 3 was found to be a mild acid (Richards, 1954). Salt values were classified according to Richards (1954) and all soils determined to be non-saline. The lime contents of soil samples: $41.67 \%$ of the soil samples contain trace amounts, $20.83 \%$ slight amounts, $12.50 \%$ medium amounts and $25.00 \%$ abundant amounts of lime (Anonymous, 1988). The organic matter contents of soils: Samples no. 2 and 5 contain trace levels and samples no. 1, 4, 9, 11, 20, 21 and 24 contain low levels of organic matter. On the other hand samples no. 3, 6, 7, 8, 12, 13, 17, 18, 22 and 23 contained medium levels of organic matter; and samples no. 10,14, 15, 16 and 19 had a good content of organic matter (Anonymous, 1988). Doğan et al. (2013), stated that according to the thematic maps created by IDW (Inverse distance weight method), the lime contents of Şebinkarahisar district soils are at high levels. Sağlam (2001) discussed that a large part of Turkey's soils, in general, contains organic matter in low to medium levels. High values could also be found partly.

The amounts of lime and organic matter are the most effective factors on the nitrogen usefulness in the soil. It is very important to know the amounts of lime of soils in nitrogen fertilizer treatments (Bellitürk et al., 2009). In terms of total nitrogen: $16.67 \%$ of the soils contained very little amounts, $45.83 \%$ small amounts of total nitrogen. At the same time, $29.17 \%$ of the soil samples contained sufficient amounts, 8.33\% large amounts of total nitrogen (Anonymous, 1990). Sağlam (2002) reported that the Turkish soil, a great majority of which is considered to be sufficient or rich in terms of potassium, is poor in terms of phosphorus. Phosphorus $\left(\mathrm{P}_{2} \mathrm{O}_{5}\right)$ and potassium $\left(\mathrm{K}_{2} \mathrm{O}\right)$ values were interpreted according to the values given in Anonymous (1988). 20.83\% of the soil samples contained very little amounts, $45.83 \%$ a little amount, $20.83 \%$ a medium amount and $8.33 \%$ abundant amounts of phosphorus $\left(\mathrm{P}_{2} \mathrm{O}_{5}\right)$. Sample numbered 15 contains excessive amounts of phosphorus $\left(\mathrm{P}_{2} \mathrm{O}_{5}\right)$. Samples that were sufficient in amount for potassium $\left(\mathrm{K}_{2} \mathrm{O}\right)$ were $12.50 \%$ of the soil samples. $29.17 \%$ of the soil samples contained abundant amounts and 58.33\% excessive amounts of Potassium $\left(\mathrm{K}_{2} \mathrm{O}\right)$. In other words, potassium $\left(\mathrm{K}_{2} \mathrm{O}\right)$ deficiency was not detected in the study soils. The high calcium level is an indication of the neutral $\mathrm{pH}$ value required by most plants and microorganisms (Sağlam, 2001). Calcium and magnesium values of study soils were classified as specified by Alpaslan et al. (2005). $12.50 \%$ of the soil samples contained sufficient amounts of calcium. $62.50 \%$ of the soil samples contained abundant amounts, $25.00 \%$ excessive amounts of calcium. All soils used in the study were determined to contain high levels of magnesium.

Iron, manganese, copper, zinc, and boron were used by plants in very small quantities. Most soils contained sufficient amounts of micro elements, except for iron and manganese. However, their availability to plants was very low in general (Sağlam et al., 1993b). Iron quantities were classified according to Lindsay and Norvell (1969), and it was determined that 9 and 20 samples contained iron at a medium level and the rest of all contained high levels of iron. In the evaluation made following Follett (1969), the copper contents of all study soils were found to be sufficient. Zinc and manganese contents of soil, $16.67 \%$ of the soil samples contained very little amounts, $70.83 \%$ low amounts and $12.50 \%$ high amounts of zinc. Concerning samples 9 and 20 had very little amounts; whereas samples 5, 8, 10, 11, 12, 14, 15, 16 and 23 had little amounts of manganese content. Samples 3, 4, 6, 7, 13, 17, 21 and 24 contained sufficient amounts of manganese; and samples 1, 2, 18, 19 and 22 contained abundant amounts of manganese (Anonymous, 1990). 62.50\% of the soil samples contained a small amount, $29.17 \%$ sufficient amounts, 8.33\% abundant amounts of boron (Bray, 1948).

\section{Conclusion}

The findings showed that 22 of the 24 samples taken as surface soil from the eastern-northeastern slopes of Dikmen Hill, a volcanic cone, were in clay texture class, 17 samples had field capacity values of more than $40 \%$, and the wilting point values of 14 samples are less than $30 \%$. Available water content of most of the samples were more than $10 \%$. The findings revealed that the particle density and bulk density values of soil samples were close to each other within themselves. Their total porosity values were found to be over $40 \%$. Almost all soil samples had neutral and slightly alkaline soil reactions, and all soil samples were determined to be non-saline. The lime values of the majority of samples were very little, little and medium. Barnyard manure application is recommended especially for deficient 
and medium level of organic matter. There were no potassium, calcium and magnesium deficiencies in the study soils. On the other hand, in 15 samples total nitrogen, and in 16 samples phosphorus deficiency was determined, and there were also soils containing phosphorus in medium level. No trace of copper deficiency was found. The iron content was high in almost all of the soils. In 21 samples zinc, in 11 samples manganese, and in 15 samples boron deficiencies were determined. Before agricultural treatments on the study area soils with volcanic soil characteristics, especially the analysis of nitrogen and available phosphorus, and for the preparation of an appropriate fertilization program according to macro and micronutrient elements, carrying out preagriculture soil analyses, are recommended. It is suggested that the preference of especially barnyard manure and organic fertilizers are highly likely to be appropriate when a fertilization program is made.

\section{References}

Akbaș, B., Akdeniz, N., Aksay, A., Altun, İ., Balcı, V., Bilginer, E., Bilgiç, T., Duru, M., Ercan, T., Gedik, İ., Günay, Y., Güven, İ. H., Hakyemez, H. Y., Konak, N., Papak, İ., Pehlivan, Ş., Sevin, M., Şenel, M., Tarhan, N., Turhan, N., Türkecan, A., Ulu, Ü., Uğuz, M. F., Yurtsever, A. ve diğerleri. 2015. Türkiye Jeoloji Haritası. Maden Tetkik ve Arama Genel Müdürlüğü Yayını, Ankara, Türkiye.

Alpaslan, M., Güneş, A., İnal, A., 2005. Deneme Tekniği (2. Baskı). Ankara Üniversitesi Ziraat Fakültesi Yayın No: 1543, Ders Kitabı: 496, Ankara, 437 s.

Anonymous, 1988. Türkiye Gübre ve Gübreleme Rehberi. Toprak ve Gübre Araştırma Enstitüsü Müdürlüğü, Ankara.

Anonymous, 1990. Micronutrient Assessment at the Country Level: An International Study. FAO Soils Bulletin (FAO) No: 63, by Sillanpaeae, M., Rome.

Anonymous, 1993. Soil Survey Manual. Soil Conservation Service, U.S. Department of Agriculture Handbook No: 18, Washington D.C., USA, 437 pp.

Anonymous, 2015. Maden Tetkik ve Arama Genel Müdürlüğü (MTA). Yerbilimleri Harita Görüntüleyici ve Çizim Editörü (Version 2.5). Bilimsel Dökümantasyon ve Tanıtma Dairesi. (Web sayfası: ttp://yerbilimleri.mta.gov.tr/anasayfa.aspx (Erişim tarihi: 10.07.2017).

Anonymous, 2016. T.C. Giresun Valiliği. Giresun ili haritası. (Web sayfası: http://www.giresun.gov.tr/ilimizinharitasi), (Erişim tarihi: 04.12.2016).
Anonymous, 2017a. Giresun Meteoroloji İstasyon Müdürlüğü Verileri, Giresun / Türkiye.

Anonymous, 2017b. ArcGIS Online - Esri (Cloud-based mapping platform). (Web page: http://www. esri.com/software/arcgis/ arcgisonline), (Date accessed: July 29, 2017 - August 20, 2017).

Atalay, İ., 2014. Toprak, Bitki ve Çölleşme Atlası. İnkılâp Kitabevi, Yayıncı ve Matbaa Sertifika No: 10614, İstanbul, $124 \mathrm{~s}$.

Aydın, M., Kılıç, Ş. 2010. Toprak Bilimi. Nobel Yayın Dağıtım Tic. Ltd. Şti., Nobel Yayın No: 1568, Ankara, $130 \mathrm{~s}$.

Baver, L. D., 1956. Soil Physics (Third Edition). John Wiley and Sons, Inc., New York.

Bellitürk, K., Danışman, F., Sözübek, B., 2009. The relationship between mineralization capacities and physical and chemical properties of the soils in Tekirdag Region/Turkey. Akdeniz University Journal of the Faculty of Agriculture, 22 (2): 141147.

Black, C. A., 1965. Methods of Soil Analysis. Part 1 and 2. Physical and Mineralogical Properties, Including Statistics of Measurement and Sampling; Chemical and Microbiological Properties. American Society of Agronomy, Inc., Publisher Madison, Wisconsin, USA, $1572 \mathrm{pp}$.

Bouyoucos, G. J., 1951. A recalibration of the hydrometer method for making mechanical analysis of soils. Agronomy Journal, 43: 434-438.

Bray, R. H., 1948. "Correlation of Soil Tests with Crop Response to Added Fertilizers and with Fertilizer Requirement, 53-86". Diagnostic Techniques for Soils and Crops, Chapter II. In: H. B. Kitchen (ed). The American Potash Institute, Washington D.C., 308 pp.

Burns, B. R., Dodd, M. B., Hartnett, T., 2013. Auckland's green volcanic heart: groundcover vegetation and soils of the Auckland volcanic cone reserve network. Journal of the Royal Society of New Zealand, 43 (4): 184-197.

Cangir, C., 1991. Toprak Bilgisi. Trakya Üniversitesi Tekirdağ Ziraat Fakültesi Yayın No: 116, Ders Kitabı No: 5, Tekirdağ, $178 \mathrm{~s}$.

Cangir, C., Boyraz, D. 2006. Jeoloji (Jeopedoloji). Baskı: Avcı Ofset (İstanbul), Tekirdağ, $253 \mathrm{~s}$.

Çakıroğlu, E., Korkut, C., 1950. Genel Coğrafya Dersleri. Eğitim Enstitüleri Yayımlarından: 10, Milli Eğitim Basımevi, İstanbul, $172 \mathrm{~s}$. 
Dingil, M., Șenol, S., Akça, E., Öztekin, M. E., 2012. Andic soil properties and classifications of soils formed on volcanic ashes in Turkey. Yüzüncü Yll University Journal of Agricultural Sciences, 22 (2): 108-112.

Doğan, H. M., Yılmaz, D. S., Kılıç, O. M., 2013. Mapping and interpreting some soil surface properties of Central Kelkit Basin by inverse distance weighted (IDW) method. Gaziosmanpasa Journal of Scientific Research, 6, 46-54.

Erinç, S., 2012. Jeomorfoloji I (Güncelleştirenler: Ertek A., Güneysu C.). Güncelleştirilmiş Yeni Basım. Der Yayınları: 284, İstanbul, $614 \mathrm{~s}$.

Follett, R. H., 1969. Zn, Fe, Mn, and $\mathrm{Cu}$ in Colorado Soils. Colorado State University, Ph.D. Dissertation, USA, $133 \mathrm{pp}$.

Georgoulias, F. A., Moustakas, N. K. 2010. Exploration of soils developing on volcanic materials on the island of Milos, Greece. Catena, 81 (1): 43-54.

Gürgen, G., 1997. Şebinkarahisar-Alucra çevresinde volkanik şekiller. Ankara Üniversitesi Türkiye Coğrafyası Araştırma ve Uygulama Merkezi Dergisi, 6: 149-161.

Kacar, B., 1995. Bitki ve Toprağın Kimyasal Analizleri. III. Toprak Analizleri. Ankara Üniversitesi Ziraat Fakültesi Eğitim, Araştırma ve Geliştirme Vakfı Yayınları No: 3, Ankara, 705 s.

Kacar, B., 2009. Toprak Analizleri (Genişletilmiş 2. Basım). Nobel Yayın No: 1387, Ankara, 467 s.

Karaçal, İ., 2008. Toprak Verimliliği (1. Basım). Nobel Yayın No: 1335, Ankara, 222 s.

Kervyn, M., Ernst, G. G. J., Carracedo, J. C., Jacobs, P. 2012. Geomorphometric variability of "monogenetic" volcanic cones: Evidence from Mauna Kea, Lanzarote and experimental cones. Geomorphology, 136 (1): 59-75.

Keskin, İ., 2006. Şebinkarahisar (Giresun) Yöresindeki Kaya Şevlerinin Duraylılı̆̆ının Kinematik Analizi ve Yapısal Yaklaşım. Cumhuriyet Üniversitesi Fen Bilimleri Enstitüsü, Yüksek Lisans Tezi, Sivas, Türkiye, $80 \mathrm{~s}$.

Ketin, İ., 1966. Tectonic units of Anatolia (Asia Minor). Bulletin of the Mineral Research and Exploration, 66: 23-34.

Lindsay, W. L., Norvell, W. A. 1969. Equilibrium relationships of $\mathrm{Zn} 2+, \mathrm{Fe} 3+, \mathrm{Ca} 2+$ and $\mathrm{H}+$ with EDTA and DTPA in soils. Soil Science Society of America Journal, 33 (1): 62-68.

Neall, V. E., 2009. "Volcanic Soils, 23-45”. Encyclopedia of Land Use, Land Cover and Soil Sciences, Soils and Soil Sciences (Part 2). Volume VII. In: W. H. Verheye (ed). EOLSS Publishers / UNESCO, EOLSS
Publishers Company Limited, Oxford, United Kingdom, 235 pp.

Özcan, A. K., 2011. Türkiye jeolojisi çalışma notları. 17 s. (Web sayfasi: https://kursatozcan.com /ders_notlari/kursat_ozcan_turkiye_jeolojisi.pdf (Erişim tarihi: 09.06.2016).

Özdemir, N., Öztürk, E., Yakupoğlu, T. 2008. Effects of parent material and land use on distribution of some trace elements fractions in soil. The Journal of Agricultural Faculty of Ondokuz Mayıs University, 23 (2): 92-97.

Richards, L. A., 1954. Diagnosis and Improvement of Saline and Alkali Soils. United States Department of Agriculture Handbook No: 60, U.S. Government Printing Office, Washington D.C., 160 pp.

Sağlam, M. T., Cangir, C., Bahtiyar, M., Tok, H. H. 1993a. Toprak Bilimi. Trakya Üniversitesi Tekirdağ Ziraat Fakültesi Yayınları, Tekirdağ, 127-162 s.

Sağlam, M. T., Cangir, C., Bahtiyar, M., Tok, H. H. 1993b. Toprak Bilimi. Trakya Üniversitesi Tekirdağ Ziraat Fakültesi Yayınları, Tekirdağ, 230 s.

Sağlam, M. T., 2001. Toprak Kimyası (Genişletilmiş Üçüncü Baskı). Trakya Üniversitesi Tekirdağ Ziraat Fakültesi Yayın No: 190, Ders Kitabı No: 21, Tekirdağ, $240 \mathrm{~s}$.

Sağlam, M. T., 2002. Gübreler ve Gübreleme (Altıncı Baskı). Trakya Üniversitesi Tekirdağ Ziraat Fakültesi Yayın No: 149, Ders Kitabı No: 74, Tekirdağ, 363 s.

Sağlam, M. T., 2008. Toprak ve Suyun Kimyasal Analiz Yöntemleri (Dördüncü baskı). Namı Kemal Üniversitesi Ziraat Fakültesi Yayın No: 2, Ders Kitabı No: 2, Tekirdağ, $154 \mathrm{~s}$.

Saygıll, R., 2015. Türkiye dilsiz mülki idare haritası. (Web sayfası:http://cografyaharita.com/haritalarim/4jtu rkiye-dilsiz-siyasi-haritasi.png (Erişim tarihi: 07.05.2017)

Şenol, H., Özaytekin, H. H, Akgül, M., Alaboz, P., 2014. Effect of aspect on weathering rates and clay mineralogy of soils developed on andesite/trachyandesite parent materials under semi-arid conditions. Journal of Agricultural Sciences, 20: 288-301.

Uzun, C., 2013. Farklı Yaşlardaki Volkanik Materyal Üzerinde Oluşan Toprakların Ayrışma Oranlarının Belirlenmesi. Selçuk Üniversitesi Fen Bilimleri Enstitüsü, Doktora Tezi, Konya, Türkiye, 146 s.

Veihmeyer, F. J., Hendrickson, A. H., 1949. Methods of measuring field capacity and permanent wilting percentage of soils. Soil Science, 68 (1): 75-94.

Wolf, B., 1971. The determination of boron in soil extracts, plant materials, composts, manures, water and 
nutrient solutions. Communications in Soil Science and Plant Analysis, 2 (5): 363-374.

Yılmaz, A., Okay, A. I., Bilgiç, T., 1985. Yukarı Kelkit Çayı Yöresi ve Güneyinin Temel Jeoloji Özellikleri ve Sonuç Raporu. MTA Genel Müdürlüğü, Rapor No: 7777, Ankara, 207 s.

Yılmaz, G., 2006. Şehir Coğrafyası Açısından Şebinkarahisar. İstanbul Üniversitesi Sosyal Bilimler Enstitüsü, Yüksek Lisans Tezi, İstanbul, Türkiye, $145 \mathrm{~s}$.
Yılmaz, S., 1995. Dereli-Şebinkarahisar (Giresun Güneyi) Arası Granitoyid Plütonlarının Karşılaștırmalı İncelenmesi. Cumhuriyet Üniversitesi Fen Bilimleri Enstitüsü, Doktora Tezi, Sivas, Türkiye, $310 \mathrm{~s}$.

Yürüdür, E., 1998. Şebinkarahisar ve Çevresinin Coğrafi Etüdü. Atatürk Üniversitesi Sosyal Bilimler Enstitüsü, Doktora Tezi (Yayınlanmamış), Erzurum, Türkiye, $438 \mathrm{~s}$. 